\title{
Time Course Analysis of Immunolocalization of Coat Protein and Replicase Proteins in Protoplasts Inoculated with Tobacco Mosaic Virus
}

\author{
Daijiro HosoKAWA*, Yuichiro WaTANABE** and Yoshimi OKADA**
}

\begin{abstract}
The localization of coat protein and putative viral replicase proteins ( $130 \mathrm{kDa}$ and 180 $\mathrm{kDa}$ ) of tobacco mosaic virus (TMV) in tobacco protoplasts was examined at different post-inoculation intervals, using specific antibodies and protein A-gold complex. Gold labels specific to antiserum against virus particle were first detected $4 \mathrm{hr}$ postinoculation (p. i.) in small areas of the cytoplasm, where virus particles were not initially observed. At 6$15 \mathrm{hr}$ p.i. when virus multiplication was active, virus particles were accumulated and formed a paracrystalline array in the cytoplasm. Specific labels were found only on the crystalline aggregates and in the cytoplasm near the aggregates. Many virus aggregates were observed in each section of protoplasts at this stage. At $24 \mathrm{hr}$ p.i., larger aggregates of virus particles were heavily labelled, while areas of the cytoplasm, where no virus particles were evident, were labelled scarcely. Nuclei, plastids and mitochondria were free of labels throughout the infection stages. Gold labels for $130 \mathrm{kDa}$ protein were first detected on small TMV-specific inclusions in the cytoplasm at $4 \mathrm{hr}$ p.i.: Thereafter, these inclusions grew both in number and size, and occurred frequently in the vicinity of virus aggregates. Labels were localized on the inclusions but not on virus aggregates throughout the infection stages. Those inclusions have dense labels and grew a little further in size, though virus replication at this stage declined to a low level. Gold labels for $180 \mathrm{kDa}$ protein on the inclusions and other parts of protoplasts at each stage were observed similarly as the labels for $130 \mathrm{kDa}$ protein. These observations indicate that replication of genomic RNA, synthesis of coat protein and subsequent virus assembly do take place at limited areas in the cytoplasm, where virus particles appeared and formed crystalline aggregate at later stages.
\end{abstract}

(Received July 3, 1992)

Key words : tobacco mosaic virus, replicase genes, coat protein, immunogold electron microscopy.

\section{INTRODUCTION}

Tobacco mosaic virus (TMV) is a rod-shaped virus with a length of $300 \mathrm{~nm}$ and a diameter of $18 \mathrm{~nm}$, made up of about 2,100 subunits of a single coat protein species and a single-stranded messenger-sense genomic RNA. This genomic RNA is about 6,400 nucleotides long and encodes at least four proteins ; three non-structural proteins $(130 \mathrm{kDa}, 180 \mathrm{kDa}$, and $30 \mathrm{kDa})$ and $17.5 \mathrm{kDa}$ coat protein ${ }^{5.11}$.

Establishment of in vitro transcription of infectious RNA from full-length cDNA of TMV ${ }^{2,7,101}$ enabled us to reveal the functions of these viral proteins by reverse-genetic approaches. The techniques

- Faculty of Agriculture, Tokyo University of Agriculture and Technology, Fuchu, Tokyo 183, Japan 東京農 工大学農学部

** Department of Biosciences, Teikyo University, Toyosato-dai 1-1, Utsunomiya, Tochigi 320, Japan 帝京大学 バイオサイエンス学科 
of making transgenic plants in parallel but in part contributed to the clarification of functions. $130 \mathrm{kDa}$ and $180 \mathrm{kDa}$ proteins are considered to be components of TMV replicase ${ }^{6)}$. The $30 \mathrm{kDa}$ protein functions in cell-to-cell movement of the virus in plant tissues ${ }^{3,8)}$, presumably through plasmodesmata ${ }^{1,17)}$. The coat protein is used for encapsidation of the newly synthesized genomic RNA into virus particles and also involved in long-distance movement, like from one leaf to another ${ }^{14,16)}$.

Previously we have investigated the temporal profiles of synthesis of these TMV-encoded proteins and corresponding mRNA in protoplasts which were synchronously inoculated with viral RNA ${ }^{19,20)}$. The protoplast system has several advantages over the intact plant system. First, many cells are able to be simultaneously inoculated with virus at a high frequency. Secondly, protoplasts from suspension culture cells have relatively small vacuoles and rather abundant cytoplasm. Vacuoles in cells of intact plant tissues usually occupy a large fraction of cell volume and leave a small fraction for cytoplasm between vacuoles and along with the cell membrane. Use of the protoplast system provides an opportunity to look more closely the events occuring in the cytoplasm after virus infection. In this paper, we demonstrate intracellular localization of the TMV -encoded proteins $(130 \mathrm{kDa}, 180 \mathrm{kDa}$ and coat proteins) in protoplasts as a function of time after inoculation by using specific antibodies and protein A.gold complex, and discuss the spatial relation of virus replication and virus assembly sites.

\section{MATERIALS AND METHODS}

Virus. The Japanese common strain of TMV $(\mathrm{OM})$, which was propagated in Nicotiana tabacum L. cv. Xanthi, was used. TMV RNA was prepared from purified virus as described previously ${ }^{10)}$.

Antisera. Anti-TMV serum was produced by injecting rabbits with virus preparations purified by differential and sucrose density gradient centrifugations. Antibody titer against purified TMV was $1 / 1024$ in the microprecipitin test. Western blot analysis showed that the antiserum is also highly reactive to monomeric coat protein subunits (data not shown) ${ }^{14}$.

Antisera to $130 \mathrm{kDa}$ and $180 \mathrm{kDa}$ proteins were raised separately against fusion proteins (composed of $\beta$-galactosidase and either $130 \mathrm{kDa}$ protein or $180 \mathrm{kDa}$ protein) which were produced in $E$. coli $i^{12}$.

The antiserum to $130 \mathrm{kDa}$ protein reacts with both $130 \mathrm{kDa}$ and $180 \mathrm{kDa}$ proteins, while the antiserum to $180 \mathrm{kDa}$ protein reacts only with $180 \mathrm{kDa}$ protei ${ }^{12}$. Both antisera react rarely with host proteins $^{12)}$.

Viral RNA inoculation of protoplasts. Protoplasts which were prepared from suspension culture tobacco cells (Nicotiana tabacum L. cv. BY-2) were inoculated with TMV-RNA by the electro. poration method as described previously ${ }^{20)}$. Inoculated protoplasts were cultured in modified MS medium supplemented with $0.4 \mathrm{M}$ mannitol ${ }^{18)}$ at a concentration of $2 \times 10^{5}$ protoplasts $/ \mathrm{ml}$.

Immunolocalization with antibodies and protein A-gold complex. Protoplasts were collected in $15 \cdot \mathrm{ml}$ tubes at $4,6,8,12,15,18,24$ or $48 \mathrm{hr}$ postinoculation (p.i.) by a brief centrifugation and then fixed with $2.5 \%$ glutaraldehyde in $0.1 \mathrm{M} \mathrm{Na}$ phosphate $(\mathrm{pH} 7.4)-0.4 \mathrm{M}$ mannitol, for $2 \mathrm{hr}$ at room temperature. Fixed protoplasts were treated with $0.1 \mathrm{M} \mathrm{NH}_{4} \mathrm{Cl}$ for $30 \mathrm{~min}$, rinsed with $0.1 \mathrm{M} \mathrm{Na}$ phosphate (pH 7.4), and then dehydrated in a series of ice cold ethanol $(30 \% \text { to } 100 \%)^{9)}$. Protoplasts were transferred to polyethylene capsule tubes (BEEM, USA) and packed by a brief centrifugation. The dehydrated samples were infiltrated with Lowicryl K4M (Polysciences, USA) at $-20^{\circ} \mathrm{C}$ for $24 \mathrm{hr}$ and embedded by UV-polymerization for $48 \mathrm{hr}$ at $-20^{\circ} \mathrm{C}$. Ultrathin sections were cut from embedded samples using a glass knife and mounted on formvar-coated 200 -mesh nickel grids.

The grids were floated on drops of $1 \%$ bovine serum albumin in PBS $(10 \mathrm{mM}$ Na phosphate, $\mathrm{pH} 7.2$, $150 \mathrm{mM} \mathrm{NaCl}$ ) for $30 \mathrm{~min}$ at room temperature, and then were placed on drops of antiserum at $1: 400-$ $1: 1000$ dilutions for $2 \mathrm{hr}$. The specimens were washed with PBS four times for $10 \mathrm{~min}$ each and treated with protein A-gold complex ( $15 \mathrm{~nm}$ gold particles, EY laboratory, USA) for $1 \mathrm{hr}$ at room temperature. After rinsing with PBS and then with distilled water, sections were stained with uranyl acetate for 10 $\mathrm{min}$ and then with lead citrate for $3 \mathrm{~min}$. Specimens were examined under a JEM-100C electron microscope (JEOL, Ltd., Japan). 


\section{RESULTS}

\section{Immunogold labelling for coat protein}

Specific gold labels for coat protein were first observed in restricted areas of the cytoplasm in protoplasts at $4 \mathrm{hr}$ postinoculation (Plate I-1 and 2). There were no characteristic features in cytoplasm around the areas with labels, although endoplasmic reticulum (ER) was often observed in their vicinity (Plate I-2). At this stage, virus particles were not discernible in the areas or in any other portions of the cells.

At $6 \mathrm{hr}$ p.i., labelled areas of the cytoplasm varying in sizes were found frequently in protoplasts (Plate I-3 and 4). Labelled areas especially larger ones had virus particles, some of which were arranged close each other and had an intense immunolabelling (Plate I-3, 4 and 5). Gold labels were often found in the cytoplasm just adjacent to virus aggregates (Plate I-5), where no virus particles were observed, indicating that the areas of cytoplasm can be nascent accumulation/assembly sites of coat protein.

During the period of 6 to $12 \mathrm{hr}$ p.i., crystalline virus aggregates in the cytoplasm grew larger with advance of postinoculation time. Gold labels were found exclusively in virus aggregates or in the neighboring cytoplasm at the later stage of infection as $12 \mathrm{hr}$ p.i. (Plate II-6). At $24 \mathrm{hr}$ p.i., much larger aggregates of virus particles were observed in the cytoplasm and had intense labels (Plate II-7). At this stage, gold labels were scarce in the cytoplasm where no virus particles were observed (Plate II-7). At $48 \mathrm{hr}$ p.i., virus aggregates occupied a substantial fraction of cytoplasm and were heavily labelled. Labels were observed also in the cytoplasm apart from viral crystalline aggregates. In some protoplasts, labels were noted more frequently in the cytoplasm at this stage (Plate II-8).

Granular inclusions in which $130 \mathrm{kDa}$ and $180 \mathrm{kDa}$ proteins were detected by immunogold labelling in our earlier repor ${ }^{13)}$ appeared in the vicinity of crystalline virus aggregates. The inclusions were not labelled by antiserum to TMV (Plate II-7).

The nuclei as well as plastids or mitochondria were free of labels for coat protein throughout the infection stages (Plate I-5, Plate II-6, 7 and 8).

Virus particles were occasionally observed scattering in the vacuoles at $48 \mathrm{hr}$ p.i. These virus particles might have dispersed from cytoplasm into the vacuoles due to incidental breakages of the tonoplast during the fixation or embedding process of protoplasts.

Sections from noninoculated protoplasts that were incubated with antiserum to TMV or sections from TMV-infected protoplasts that were treated with preimmune serum had few labels due to non-specific bindings.

\section{Immunogold labelling for $130 \mathrm{kDa}$ or $180 \mathrm{kDa}$ protein}

When sections of protoplasts at $4 \mathrm{hr}$ p.i. were treated with antiserum to $130 \mathrm{kDa}$ protein, gold labels were observed on infection-specific small electron-dense structures in the cytoplasm (Plate III-9). These novel electron-dense structures are considered to correspond to a premature form of the granular inclusions which we have previously reported in TMV-infected tobacco leaf cells ${ }^{13}$. At $6 \mathrm{hr}$ p.i., inclusions grew further both in number and size (Plate III-10).

At $12 \mathrm{hr}$ p.i., many heavily labelled inclusions varying in size and shape occurred in the cytoplasm. Larger inclusions were irregular in shape. Smaller inclusions seemed to be newly formed (Plate III-11). These inclusions were observed usually in the vicinities of virus aggregates. Labels for $130 \mathrm{kDa}$ protein were not noted in virus aggregates throughout the infection stages. At 18 or $24 \mathrm{hr}$ p.i., inclusions were even larger in size and elliptic rather than irregular in shape (Plate IV-12 and 13). These inclusions contained fibrillar structures and often had small electron translucent vacuole-like areas within them, but no surrounding membranes. These inclusions had intense labels (Plate IV.12 and 13). At $48 \mathrm{hr}$ p.i., inclusions were elliptic in shape, and had intense labels (Plate V-14 and 15).

Throughout the time-course analysis for $130 \mathrm{kDa}$ protein, gold labels were not observed to be associated with the other organelles such as nuclei, plastids, mitochondria and vacuoles.

When the sections of TMV-inoculated protoplasts were treated with antiserum to $180 \mathrm{kDa}$ protein, which reacts to $180 \mathrm{kDa}$ protein but not to $130 \mathrm{kDa}$ protein, gold labels were observed only on the 
granular inclusions which were tagged with antiserum to $130 \mathrm{kDa}$ protein. However, the number of labels on the inclusions was less than that observed when sections were labelled for $130 \mathrm{kDa}$ protein (Plate VI-16) as described earlier ${ }^{13}$.

Specific labelling for either $130 \mathrm{kDa}$ or $180 \mathrm{kDa}$ proteins was observed neither on sections of mock-inoculated protoplasts nor on sections of TMV-infected protoplasts treated by preimmune serum, except a few scattering labels that seemed to be non-specific.

\section{DISCUSSION}

In TMV-infected protoplasts, gold labels for $130 \mathrm{kDa}$ and $180 \mathrm{kDa}$ proteins were observed only in granular inclusions in the cytoplasm. These proteins are involved in the synthesis of genomic RNA ${ }^{6}$ and presumably also in subgenomic $\mathrm{RNAs}^{21}$. Combining available informations, it can be imagined that subgenomic mRNA for coat protein was first synthesized within or around the granular inclusions. It has been shown that TMV accumulation in protoplasts was completely inhibited by cycloheximide but not by chloramphenicol ${ }^{15}$. This fact indicates that $80 \mathrm{~S}$ ribosomes in the cytoplasm are used for virus protein synthesis but not $70 \mathrm{~S}$ ribosomes in organelles. In TMV-infected protoplasts, viral mRNAs moved to 80 $\mathrm{S}$ ribosomes to form large polyribosomes, where a large amount of coat proteins is produced. During the stage of vigorous virus replication, gold labels for coat protein were found on crystalline virus aggregates and nearby cytoplasm where no virus particles were observed, indicating that the cytoplasm adjacent to crystalline virus aggregates with gold labels is the main site for coat protein synthesis in TMV-infected protoplasts. Encapsidation of genomic RNA into virions could occur at the periphery or inside the virus aggregates. Consistent with this idea, the putative area, where genomic RNAs are synthesized/replicated, is in or around the granular inclusions which are located near crystalline virus aggregates. Newly formed virus particles are incorporated into crystalline aggregates. During the later course of infection in protoplasts when virus multiplication slowed down, coat protein antigens were found also in the cytoplasm apart from virus aggregates. These antigens could be regarded as free coat protein which were synthesized in excess than the amount necessary for encapsidation of genomic RNA.

Our observation showed that $130 \mathrm{kDa}$ and $180 \mathrm{kDa}$ proteins which are responsible for the RNA synthesis were detected exclusively in the granular inclusions. In our protoplast system, the synthesis of TMV-RNA (genomic RNA) and subgenomic mRNA for the $30 \mathrm{kDa}$ and coat proteins is first observed at 2-4 $\mathrm{hr}$ p.i., reached to the maximum level at $6-8 \mathrm{hr}$ p.i. ${ }^{18}$ ) and then declined. The granular inclusions were smaller in size at the early stage of infection when virus multiplication was vigorous. And the inclusions grew larger after the synthesis of TMV-RNA declined considerably. These observations indicate that only a small proportion of $130 \mathrm{kDa}$ and $180 \mathrm{kDa}$ proteins observed in inclusions are used actually in RNA synthesis whether or not the RNA replication site is the inclusions. Probably, most of the $130 \mathrm{kDa}$ and $180 \mathrm{kDa}$ proteins are functional at the early stages but they are accumulated as a biologically inactive entity and form dense granules. This situation coincides with the model postulated for cowpea mosaic virus (CPMV)', where non-structural proteins involved in replication of CPMV-RNA is able to synthesize only one RNA molecule each and thereafter accumulate in the cytoplasm as inactive molecules.

This work was supported in part by a Grant-in-Aid from the Ministry of Education, Science and Culture, Japan.

\section{Literature cited}

1. Atkins, D., Hull, R., Wells, B., Roberts, K., Moore, P. and Beachy, R.N. (1991). The tobacco mosaic virus $30 \mathrm{~K}$ movement protein in transgenic tobacco plants is localized in plasmodesmata. J. Gen. Virol. 72 : 209211.

2. Dawson, W.O., Beck, D.L., Knorr, D.A. and Grantham, G.L. (1986). cDNA cloning of the complete genome of tobacco mosaic virus and production of infectious transcripts. Proc. Natl. Acad. Sci. USA $83: 1832-1836$.

3. Deom, C.M., Oliver, M.J. and Beachy, R.N. (1987). The 30-kilodalton gene product of tobacco mosaic virus 
potentiates virus movement. Science $237: 389-394$.

4. Eggen, R., Kaan, A., Goldbach, R. and van Kammen, A. (1988). Cowpea mosaic virus RNA replication in crude membrane fractions from infected cowpea and Chenopodium amaranticolor. J. Gen. Virol. 69 : 27112720.

5. Goelet, P., Lomonossoff, G.P., Butler, P.J.G., Akam, M.E., Gait, M.J. and Karn, J. (1982). Nucleotide sequence of tobacco mosaic virus RNA. Proc. Natl. Acad. Sci. USA $79: 5818-5822$.

6. Ishikawa, M., Meshi, T., Motoyoshi, F., Takamatsu, N. and Okada, Y. (1986). In vitro mutagenesis of the putative replicase genes of tobacco mosaic virus. Nuc. Acids. Res. $14: 8291-8305$.

7. Meshi, T., Ishikawa, M., Motoyoshi, F., Semba, K. and Okada, Y. (1986). In vitro transcription of infectious RNAs from full-length cDNAs of tobacco mosaic virus. Proc. Natl. Acad. Sci. USA 83 : 5043-5047.

8. Meshi, T., Watanabe, Y., Saito, T., Sugimoto, A., Maeda, T. and Okada, Y. (1987). Function of the $30 \mathrm{kD}$ protein of tobacco mosaic virus: involvement in cell-to-cell movement and dispensability for replication. EMBO J. $6: 2557-2563$.

9. Meshi, T., Hosokawa, D., Kawagishi, M., Watanabe, Y. and Okada, Y. (1992). Reinvestigation of intracellular localization of the $30 \mathrm{~K}$ protein in tobacco protoplasts infected with tobacco mosaic virus RNA. Virology 187: 809-813.

10. Nejidat, A., Cellier, F., Holt, C.A., Gafny, R., Eggenberger, A.L. and Beachy, R.N. (1991). Transfer of the movement protein gene between two tobamoviruses : influence on local lesion development. Virology 180 : 318-326.

11. Ohno, T., Aoyagi, M., Yamanashi, Y., Saito, H., Ikawa, S., Meshi, T. and Okada, Y. (1984). Nucleotide sequence of the tobacco mosaic virus (tomato strain) genome and comparison with the common strain genome. J. Biochem. 96 : 1915-1923.

12. Saito, T., Watanabe, Y., Meshi, T. and Okada, Y. (1986). Preparation of antibodies that react with the large non-structural proteins of tobacco mosaic virus by using Escherichia coli expressed fragments. Mol. Gen. Genet. $205: 82-89$.

13. Saito, T., Hosokawa, D., Meshi, T. and Okada, Y. (1987). Immunocytochemical localization of the $130 \mathrm{~K}$ and $180 \mathrm{~K}$ proteins (putative replicase components) of tobacco mosaic virus. Virology $160: 477-481$.

14. Saito, T., Yamanaka, K., Watanabe, Y., Takamatsu, N., Meshi, T. and Okada, Y. (1989). Mutational analysis of the coat protein gene of tobacco mosaic virus in relation to hypersensitive response in tobacco plants with the $\mathrm{N}^{\prime}$ gene. Virology $173: 11-20$.

15. Sakai, F. and Takebe, I. (1974). Protein synthesis in tobacco mesophyll protoplasts induced by tobacco mosaic virus infection. Virology $62: 426-433$.

16. Takamatsu, N., Ishikawa, M., Meshi, T. and Okada, Y. (1987). Expression of bacterial chloramphenicol acetyltransferase gene in tobacco plants mediated by TMV-RNA. EMBO J. 6 : 307-311.

17. Tomenius, K., Clapham, D. and Meshi, T. (1987). Localization by immunogold cytochemistry of the virus-coded $30 \mathrm{~K}$ protein in plasmodesmata of leaves infected with tobacco mosaic virus. Virology $160: 363-$ 371.

18. Watanabe, Y., Ohno, T. and Okada, Y. (1982). Virus multiplication in tobacco protoplasts inoculated with tobacco mosaic virus RNA encapsulated in large unilamellar vesicle liposomes. Virology $120: 478-480$.

19. Watanabe, Y., Emori, Y., Ooshika, I., Meshi, T., Ohno, T. and Okada, Y. (1984). Synthesis of TMV-specific RNAs and proteins at the early stage of infection in tobacco protoplasts: Trasient expression of the $30 \mathrm{~K}$ protein and its mRNA. Virology $133: 18-24$.

20. Watanabe, Y., Meshi, T. and Okada, Y. (1987). Infection of tobacco protoplasts with in vitro transcribed tobacco mosaic virus RNA using an improved electroporation method. FEBS Lett. 219: 65-69.

21. Watanabe, Y., Morita, N., Nishiguchi, M. and Okada, Y. (1987). Attenuated strains of tobacco mosaic virus reduced synthesis of a viral protein with a cell-to-cell movement function. J. Mol. Biol. 194 : 699-704.

和 文 摘

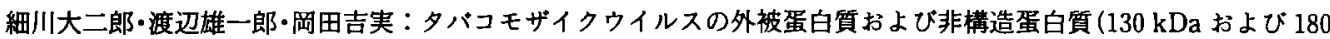
$\mathrm{kDa}$ 蛋白質)のタバコプロトプラストにおける局在の経時的観察

タバコモザイクウイルス(TMV)の外被蛋白質および非構造虽白質 $(130 \mathrm{kDa}$ および $180 \mathrm{kDa}$ 蛋白質)のタバコブロ トプラストにおける局在をプロテイン A-金コロイド法を用いて検討した。外被蛋白質の抗体では, 金粒子の標識が接 種 4 時間後に最初に細胞質の一部に認められた。その後,この初期の金粒子の標識部位は細胞質に数力所認められるよ うになり,やがてこの部位には TMV 粒子が観察された。TMV 粒子は結晶配列の集塊となり，集塊の大きさが急速に 
増加したが、この期間，金粒子はウイルス粒子の集塊とその近傍にのみ観察された。ウイルスの增殖が定常期に達する 時期(接種 24 時間後)には金粒子の標識はウイルス粒子の認められない細胞質にも広く観察されるようになった。核, プラスチド,ミトコンドリアにはいずれの時期にも金粒子の標識は認められなかった。130 kDa 蛋白質の抗体では, 金 粒子の標識が接種 4 時間後に細胞質の形成初期の顆粒状封入体に認められた。その後, この封入体は数を增し，ウイル ス粒子の果塊の近傍に観察され，形態は不定型から棈円形へと変化し，その大きさが増加したが，金粒子の標識はこの 封入体にのみ認められた。180 kDa 蛋白質の抗体では, 金粒子は $130 \mathrm{kDa}$ 蛋白質の認められた封入体にのみ覞察された

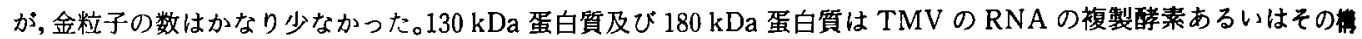
成成分であると考えられているので，以上の結果は，ウイルス RNAの複製，外被蛋白質の合成，ウイルス粒子の形成 などの TMV の増殖の過程が，細胞質の限られた部位で起こることを示していると考えられた。

\section{Explanation of plates}

Plate I Electron micrographs of TMV RNA-infected tobacco protoplasts labelled with antibody to TMV and protein A-gold. Bars represent $0.5 \mu \mathrm{m}$. ER : endoplasmic reticulum ; P : plastid ; V : virus particle.

1 and 2. Part of protoplasts at $4 \mathrm{hr}$ p.i. showing gold labels in restricted areas in the cytoplasm and nearby endoplasmic reticulum.

3-5. Part of protoplasts at $6 \mathrm{hr}$ p.i. showing gold labels in small aggregates of virus particles and in the cytoplasm near the aggregates.

Plate II Electron micrographs of TMV RNA-infected tobacco protoplasts labelled with antibody to TMV and protein A-gold. Bars represent $0.5 \mu \mathrm{m}(6$ and 8$)$ and $1 \mu \mathrm{m}(7)$. I : granular inclusion : $\mathrm{N}:$ nucleus : No: nucleolus : $\mathrm{M}:$ mitochondrion : $\mathrm{P}$ : plastid : $\mathrm{V}:$ virus particle.

6. Part of a protoplast at $12 \mathrm{hr}$ p.i. showing gold labels on an aggregate of virus particles and on cytoplasm next to the aggregate.

7. Part of a protoplast at $24 \mathrm{hr}$ p.i. showing dense gold labels on aggregates of virus particles and labels scattered on the cytoplasm. A nucleus, plastids, mitochondria and granular inclusions are free of labels.

8. Part of a protoplast at $48 \mathrm{hr}$ p.i. showing gold labels on an aggregate of virus particles and on the cytoplasm apart from the virus aggregate.

Plate III Electron micrographs of TMV RNA-infected tobacco protoplasts labelled with antiserum to $130 \mathrm{kDa}$ protein and protein A.gold. Bars represent $0.5 \mu \mathrm{m}(9$ and 10) and $1 \mu \mathrm{m}$ (11). I : granular inclusion ; P : plastid : V : virus particle: Va: vacuole.

9. Part of a protoplast at $4 \mathrm{hr}$ p.i. showing gold labels on a small electron-dense structure (nascent granular inclusion) in the cytoplasm.

10. Part of a protoplast at $6 \mathrm{hr}$ p.i. showing gold labels on a granular inclusion.

11. Part of a protoplast at $12 \mathrm{hr}$ p.i. showing gold labels on granular inclusions near aggregates of virus particles in the cytoplasm.

Plate IV Electron micrographs of TMV RNA-infected tobacco protoplasts labelled with antiserum to $130 \mathrm{kDa}$ protein and protein A-gold. Bars represent $0.5 \mu \mathrm{m}$ (12) and $1 \mu \mathrm{m}$ (13). I : granular inclusion ; P : plastid ; V : virus particle: Va: vacuole.

12. Part of a protoplast at $18 \mathrm{hr}$ p.i. showing gold labels on granular inclusions.

13. Part of a protoplast at $24 \mathrm{hr}$ p.i. showing dense gold labels on a elliptic granular inclusion.

\section{Plate V}

14 and 15. Electron micrographs of TMV RNA-infected tobacco protoplasts at $48 \mathrm{hr}$ p.i. labelled with antiserum to $130 \mathrm{kDa}$ protein and protein A-gold showing elliptic granular inclusions and surrounding large aggregates of virus particles in the cytoplasm. Bars represent $1 \mu \mathrm{m}$. I : granular inclusion : $\mathrm{N}$ : nucleus : $\mathrm{M}$ : mitochondrion : $\mathrm{P}$ : plastid : $\mathrm{V}$ : virus particle.

\section{Plate VI}

16. Electron micrograph of a TMV RNA-infected tobacco protoplast $48 \mathrm{hr}$ p.i. labelled with antiserum to $180 \mathrm{kDa}$ protein and protein A-gold showing gold labels on a granular inclusion. Bar represents $1 \mu \mathrm{m}$. I : granular inclusion : $\mathrm{P}$ : plastid : $\mathrm{V}$ : virus particle. 


\section{Plate I}
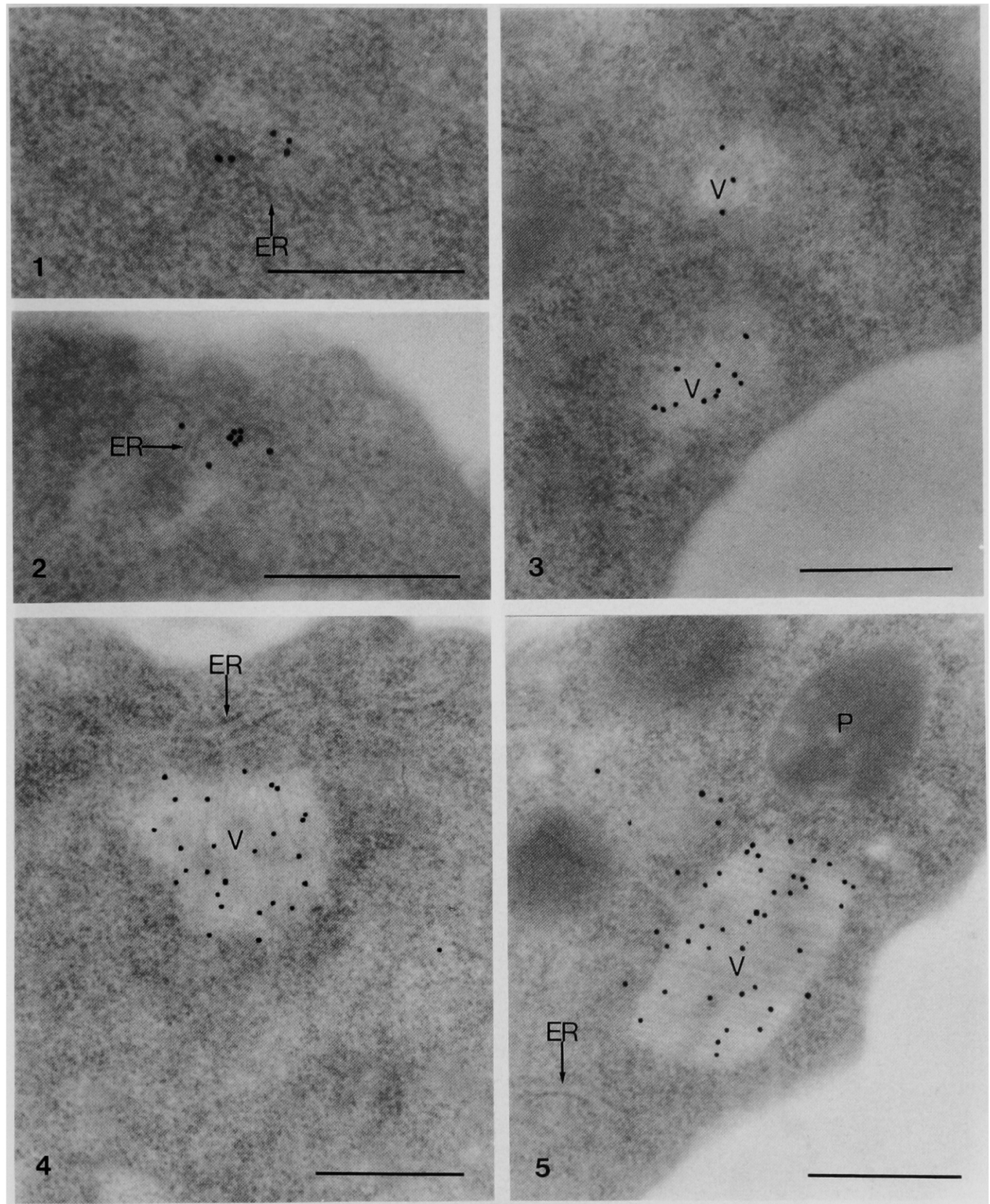


\section{Plate II}
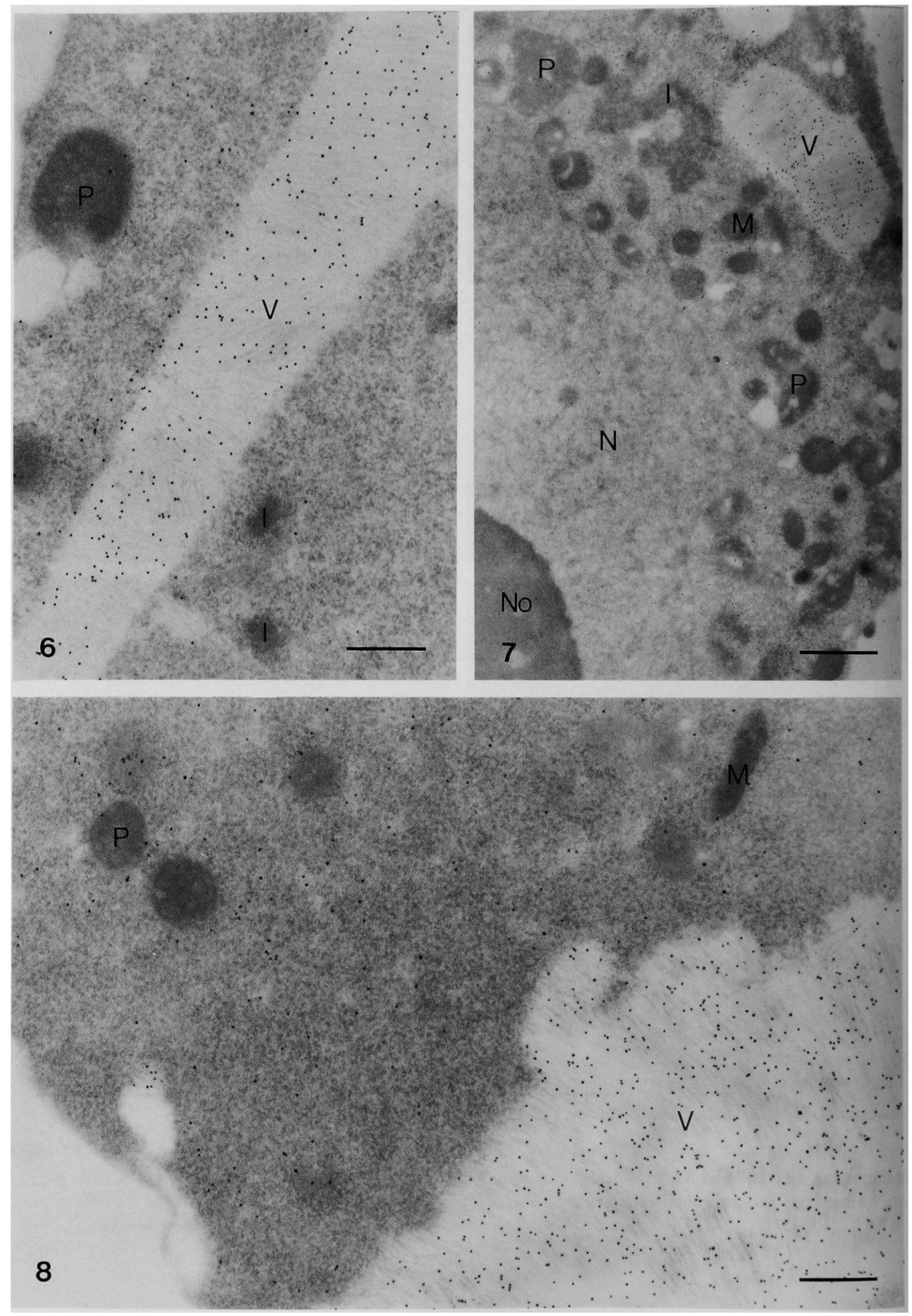


\section{Plate III}
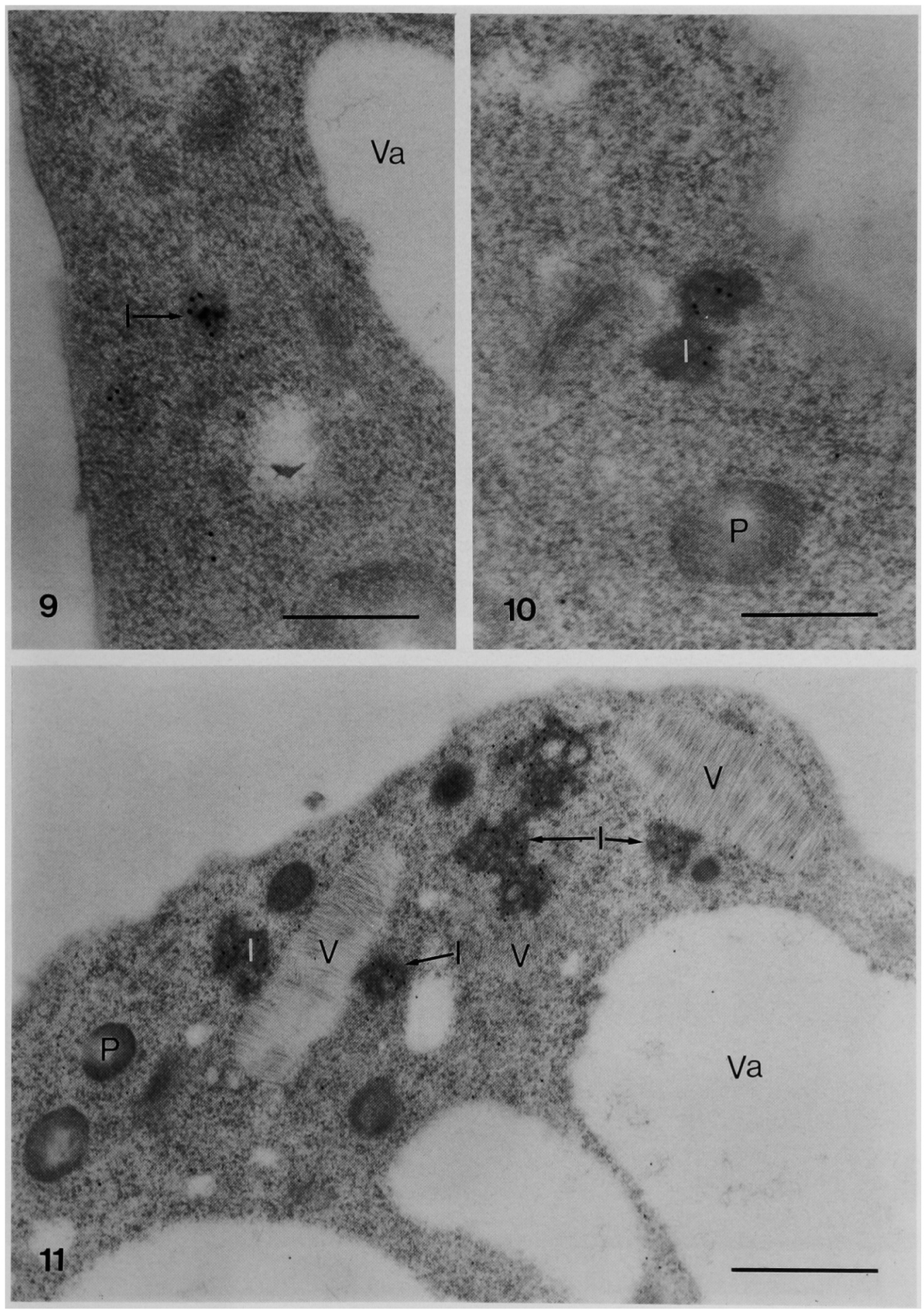


\section{Plate IV}

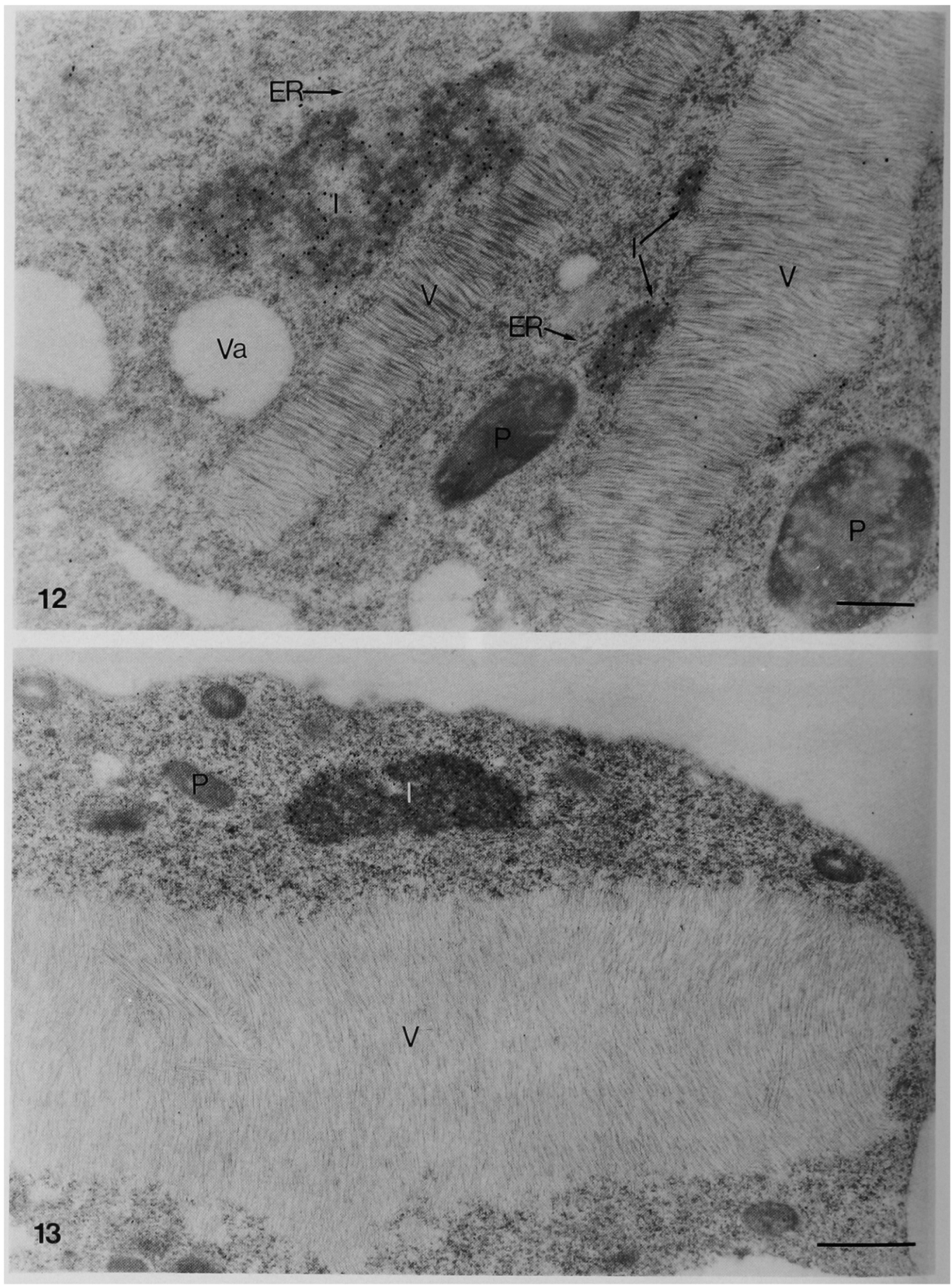




\section{Plate V}
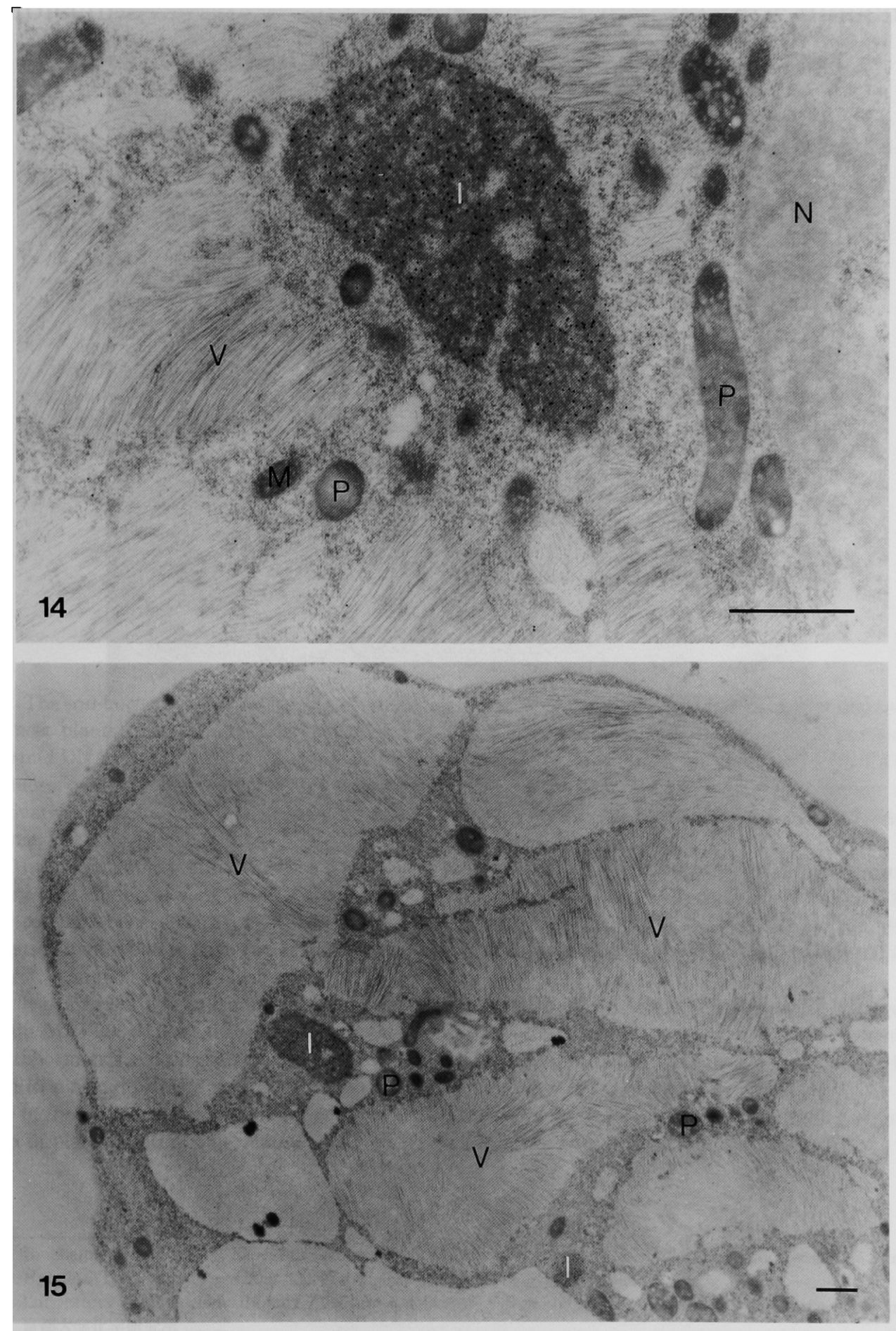


\section{Plate VI}

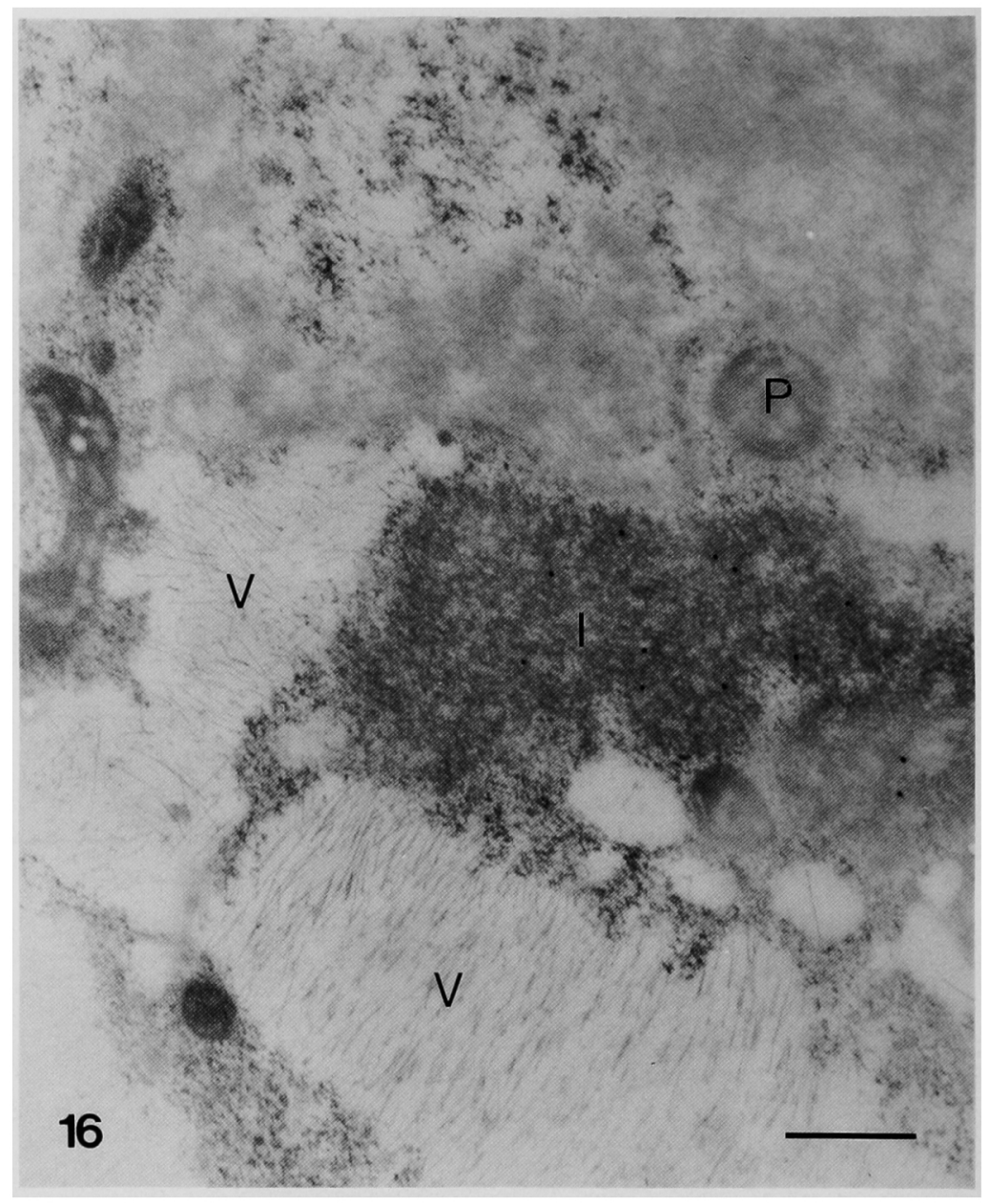

